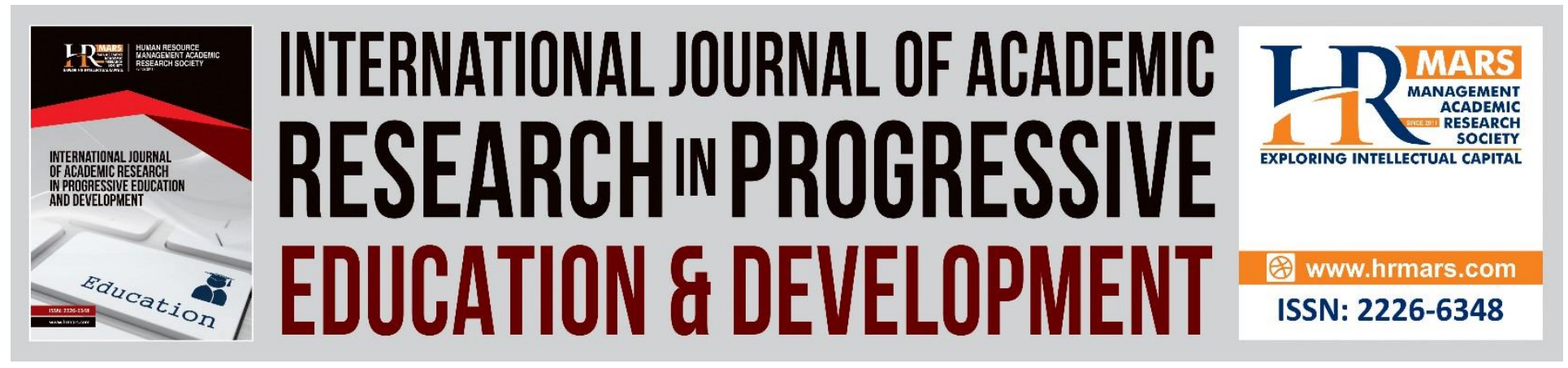

\title{
Integrating Animation with Experiential Learning Approach to Enhance Students' Engagement in the Learning Process
}

Si Min Tan, Zaleha Abdullah

To Link this Article: http://dx.doi.org/10.6007/IJARPED/v9-i4/8452

DOI:10.6007/IJARPED/v9-i4/8452

Received: 02 October 2020, Revised: 01 November 2020, Accepted: 13 December 2020

Published Online: 30 December 2020

In-Text Citation: (Tan \& Abdullah, 2020)

To Cite this Article: Tan, S. M., \& Abdullah, Z. (2020). Integrating Animation with Experiential Learning Approach to Enhance Students' Engagement in the Learning Process. International Journal of Academic Research in Progressive Education and Development, 9(4), 99-105.

Copyright: (C) 2020 The Author(s)

Published by Human Resource Management Academic Research Society (www.hrmars.com)

This article is published under the Creative Commons Attribution (CC BY 4.0) license. Anyone may reproduce, distribute, translate and create derivative works of this article (for both commercial and non-commercial purposes), subject to full attribution to the original publication and authors. The full terms of this license may be seen at: http://creativecommons.org/licences/by/4.0/legalcode

Vol. 9(4) 2020, Pg. 99 - 105

http://hrmars.com/index.php/pages/detail/IJARPED

JOURNAL HOMEPAGE

Full Terms \& Conditions of access and use can be found at http://hrmars.com/index.php/pages/detail/publication-ethics 


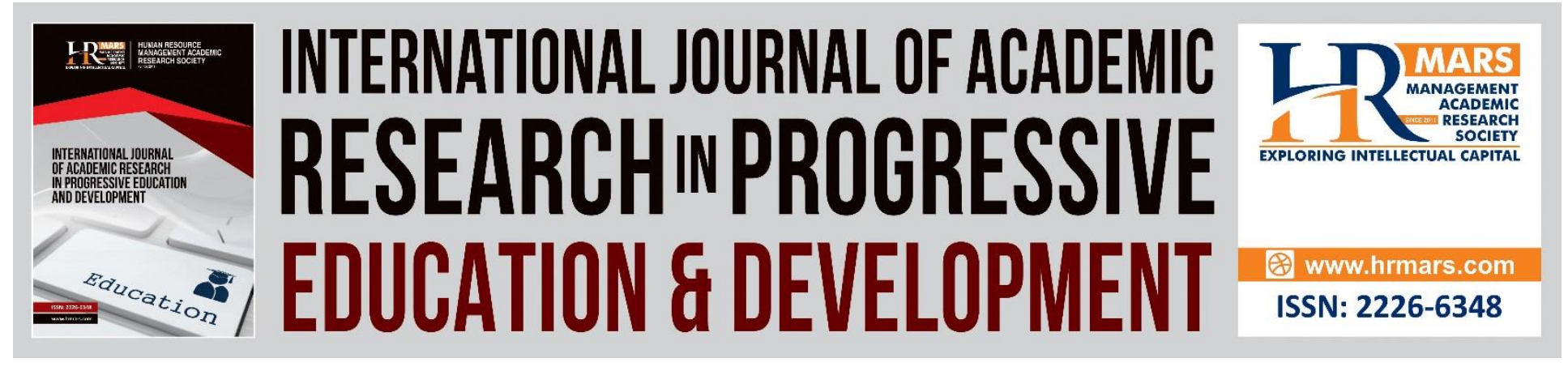

\title{
Integrating Animation with Experiential Learning Approach to Enhance Students' Engagement in the Learning Process
}

\author{
Si Min Tan, Zaleha Abdullah \\ Faculty of Social Science and Humanities, Universiti Teknologi Malaysia \\ Johor, Malaysia
}

\begin{abstract}
This paper discussed the integrating animation with experiential learning approach to enhance students' engagement in learning process. Today's young generation is expressed a strong preference for the digital world. Within the educational sphere, the development of technologies is defined as a powerful tool to create a huge number of various learning materials. From this view, the use of multimedia technologies is becoming more common in education as well as providing an extremely interesting atmosphere. In line with this, animation has been introduced for the education system since it is a part of students' daily life. Consequently, the animation must be integrated with the pedagogy such as experiential learning because the integration to foster students' engagement in the learning process. Indeed, experiential learning is imbued with students' experience. Experiential learning is a phase where learning should be student-centred because students engaged in direct contact with learning as well as experience that evokes interest in students. This paper discussed the students' engagement was boosted by the integration of animation and experiential learning.
\end{abstract}

Keywords: Multimedia Technology, Animation, Experiential Learning, Student Engagement, Learning Process.

\section{Introduction}

Increasing the advancement in information technology, the education system has gradually utilized multimedia learning. Today, teachers are no longer carrying stand in front of the classroom with a blackboard and chalk communicate information to students. Multimedia fall into category of graphical as well as interactive tool to communicate information to students. As stated by Tapscott (1998), the young generation familiarity with computers and the internet and thus they are going to expect information in the classroom to follow the same way.

In response to the need of young generation, animation has identified innovative method that teacher should use it in the classroom. Animation is a part of daily life for the young generation (Pedersen, 2011). Animation belongs to multimedia. As indicated by the literature stated that 
texts, graphics, animation, video and sound in an integrated way and the content can be structured and presented differently are a key feature of the multimedia (Inceday, 2018). The animation is an alternative method to the traditional learning by it provides a funny and entertaining learning environment. Empirical evidence documented that animation has been strongly encouraged as an innovative, constructivist and students-centered (Moreno et al., 2000; Neo \& Neo, 2009).

However, creative learning tool must not be separated from creative teaching strategy. Over the last decades, the education system is generally realized that experiential learning method is an integral part of learning. Numerous studies have proven that experiential learning was comprised one important way to improve student's interest, learning outcomes and satisfaction (Konak et al., 2014; Orús et al., 2016). Experiential learning was a great encouragement to students for engaging in activities that enable them to experience the course content (Svinivki \& McKeachie, 2011). It is our intention is about how to enhance students' engagement can be in the learning process by integrating animation with the experiential learning method.

\section{Multimedia Technology}

According to the cognitive psychology studies have shown that $94 \%$ of the information learned through the visual and auditory access, of which $88 \%$ is obtained through the vision, and $12 \%$ through hearing (Zhen, 2016). Historian researchers have proven that only $7 \%$ percent of successful communication between teachers and students come from the verbal communication, but 55\% came from visual communication as well (Hii \& Fong, 2010). From the foregoing description, Zhen (2016) concluded that, multimedia has a great potential to organize students' audio, visual and other sensory organs, and thus obtain the best of the cognitive effect. Multimedia access to knowledge is one of the possibilities of information and communication technology that has tremendous impact on learning. Through the interactive function of multimedia to foster students and effectively convey content information since the teachers display the content in an effective way. Regarding this, teachers to get students to become interested in one topic of subject and make they with a strong passion and enthusiasm to participate in teaching (Zhen, 2016). Effectively, moving from the textbook to the computer is the opportunity for greater interactivity and novel ways to think about a learning activity (Gilakjani, 2012). Many researchers have concluded that students experience deeper learning from video than from words alone (Shepard, 1967; Baggett, 1984; Salomon, 1984; Wetzel et al., 1994; Mayer \& Moreno, 2002; Mayer, 2002, 2003, 2005).

\section{Animation}

In this day and age, students derive benefit greatly from multimedia technologies such as animation. One of the best ways of showing visualization is using animation. There are studies proven that students receiving information from multiple multimedia sources and processing pictures, sounds and videos before text (Jukes et al., 2010). In fact, with respect to students learning from visual forms of presentation in the way that promote better their understanding (Mayer, 1999; Sweller, 1999). In line with the study, Roberto (2010) and Chan (2013) concluded that students have become mainly visual leaners and known as "digital generation". 
Specifically, animation is an interesting vehicle which makes teaching methods and classroom environment more engaging and entertaining as a whole. For instance, animation can assist teachers to explain and reinforce the contents in an interesting and entertaining way particularly among digital generation (Chan, 2013). Animation were evaluated as being more "engaging and credible" (Roger, 2008). Based on this definition, animation is a changing graphic visual arrangement which stimulates the view of a constant modification (Schnotz \& Lowe, 2008). There has been good evidence, animation is chosen as a reinforcement tool to nurture students' learning and engagement.

Experiential Learning

Experiential learning is soundly focused on experience. Following Li (2009) and Dewey (1973), in the learning process, experiential learning theory has emphasized the main role of experience that arouses interest in students. In the regard, students engaged in direct contact with subject through using experiential learning (Kolb, 1984). With the strength and contribution of experiential learning which cultivated and developed students' interest, satisfaction and learning outcome (Konak et al., 2014; Orús et al., 2016).

Experiential learning is the core pillar of establishing the relationship between students and learning. An experience consists of two main components that included the acquisition and transformation in the learning process. When students learn through their own experiences, it becomes more memorable (Geh, 2014). As McCarthy (2016) stated, learning as a holistic adaptive process that combines experience, perception, cognition and behaviour. Based on the investigation conducted by Dewey (1973) found that, if students unable to build up a connection with experience there are most likely to be a gap between the subject matter to be learned and the interest the subject matter.

Student Engagement

In response to the educational outcomes, student engagement is an integral part. It means student engagement indicates students' positive learning and functioning (Reeve \& Tseng, 2011). According to Fredricks et al., (2004) the definition of engagement is about a student's commitment or investment concerning their learning activities. A number of studies have proven that engagement provide a vital link with students' achievement and success in academic (Fredricks et al., 2004; Wang \& Degol, 2014; Wang \& Eccles, 2012; Chang et al., 2016). As Gunuc (2014) defined the idea of student engagement means that "what the student did for improving learning experience".

\section{Conclusion}

In the area of education, the rapid expansion of the multimedia technologies that support the learning platform for expressing the learning experience (Gunuc, 2014; Carrillo et al., 2017). Animation can be defined is a highly effective interactive multimedia tool for encouraging students be more engaged in their learning process. Additionally, education system is generally realized that experiential learning method is becoming increasingly important instrument used for learning. Experiential learning has gained widespread acceptance in the twenty-first century (Prince \& Felder, 2006; Slavich \& Zimbardo, 2012). Students have benefited greatly from experiments by learning through observation and interaction (Dedouli, 2001). Such as lived 
experiences, experimentation, simulations, role plays or viewing video and film were categorized as an experiential learning (Kolb, 1984). In conclusion, students' engagement was boosted by the integration of animation and experiential learning.

\section{Corresponding Author}

Si Min, Tan

Faculty of Social Sciences and Humanities, Universiti Teknologi Malaysia

Email: simintan@graduate.utm.my

\section{Reference}

Baggett, P. (1984). Role of temporal overlap of visual and auditory material in forming dual media associations. Journal of Educational Psychology, 76(3), 408-417.

Carrillo, R., Renaud, C., Prie, Y., \& Lavoue, E. (2017, July). Dashboard for monitoring student engagement in mind mapping activities. In 2017 IEEE 17th International Conference on Advanced Learning Technologies (ICALT) (pp. 433-437). IEEE.

Chan, C. K. (2013). Use of animation in engaging teachers and students in assessment in Hong Kong higher education. Innovations in Education and Teaching International, 52(5), 474484.

Chang, D. -F., Chien, W. -C., \& Chou, W. -C. (2016). Meta-analysis approach to detect the effect of student engagement on academic achievement. ICIC Express Letter, 10(10), 2441-2446.

Dedouli, M. (2001). Experiential learning-Possibilities of development through the framework of Flexible Zone. Inspection of educational subjects (In Greek), 12(6), 3-8.

Dewey, J. (1973). The philosophy of John Dewey: Two volume in one. Ed by, J. J. McDermott. Chicago: University of Chicago Press.

Fredricks, J. A., Blumenfeld, P. C., \& Paris, A. H. (2004). School engagement: Potential of the concept, state of the evidence. Review of Educational Research, 74(1), 59-109.

Gilakjani, A. P. (2012). A study on the impact of using multimedia to improve the quality of English language teaching. Journal of Language Teaching \& Research, 3(6), 1208-1215.

Gunuc, S. (2014). The relationships between student engagement and their academic achievement. International Journal on New Trends in Education and Their Implications, 5(4), 216-231.

Hii, S. C., \& Fong, S. F. (2010). Effects of multimedia redundancy in history learning among 'deep and surface' students. Asian Social Science, 6(6), 119-127.

Inceday, N. (2018). The impact of using multimedia technologies on students; academic achievement in the Bakirköy Final College. International Journal of Humanities Social Sciences and Education (IJHSSE), 5(1), 40-47.

Jukes, I., McCain, T. D. E., \& Crockett, L. (2010). Living on the future edge: Windows on tomorrow. Thousand Oaks, CA: Corwin.

Kolb, D. A. (1984). Experiential learning: experience as the source of learning and development. Englewood Cliffs, NJ: Prentice Hall.

Konak, A., Clark, T. K., \& Nasereddin, M. (2014). Using Kolb's experiential learning cycle to improve student learning in virtual computer laboratories. Computer \& Education, 72, 1122. 
Li, M. (2009). An examination of the role of experiential learning in the development of cultural intelligence in global leaders. Advances in global leadership, 5, 251-271.

Mayer, R. E. (1999). Multimedia aids to problem-solving transfer. International Journal of Educational Research, 31(7), 611-623.

Mayer, R., \& Moreno, R. (2002). Animation as an aid to multimedia learning. Educational Psychology Review, 14(1), 87-99.

McCarthy, M. (2016). Experiential learning theory: From theory to practice. Journal of Business \& Economics Research (JBER), 14(3), 91-100.

Moreno, R., Mayer, R., \& Lester, J. (2000). Life-like pedagogical agents in constructivist multimedia environments: Cognitive consequences of their interaction. In EdMedia + Innovate Learning (pp. 776-781). Association for the Advancement of Computing in Education (AACE).

Neo, M., \& Neo, T. K. (2009). Engaging students in multimedia-mediated Constructivist learningStudents' perception. Journal of Educational Technology \& Society, 12(2), 254-266.

Orús, C., Barlés, M. J., Belanche, D., Casaló, L., Fraj, E., \& Gurrea, R. (2016). The effect of learnergenerated videos for YouTube on learning outcomes and satisfaction. Computer \& Education, 95, 254-269.

Pedersen, H. (2011). Learning with animation. Journal of Enabling, Technologies, 5(1), 35-36.

Prince, M. J., \& Felder, R. M. (2006). Inductive teaching and learning methods: Definitions, comparisons, and research bases. Journal of engineering education, 95(2), 123-138.

Reeve, J., \& Tseng, C. M. (2011). Agency as a fourth aspect of students' engagement during learning activities. Contemporary Educational Psychology, 36(4), 257-267.

Roberto, J. (2010). Teaching \& learning with the iGeneration: Perspectives, strategies, and ideas. Lifelong Faith, 4, 45-54.

Rogers, Y. (2008). A comparison of how animation has been used to support formal, informal, and playful learning. Learning with Animation: Research Implication for Design (pp. 2863030).

Salomon, G. (1984). Television is "easy" and print is "tough": The differential investment of mental effort in learning as a function of perceptions and attributions. Journal of Educational Psychology, 76(4), 647-658.

Schnotz, W., \& Lowe, R. K. (2008). A unified view of learning from animated and static graphics. Learning with animation: Research implications for design, 304-356.

Shepard, R. (1967). Recognition memory for words, sentences, and pictures. Journal of Verbal Learning and Verbal Bahavior, 6(1), 156-163.

Slavich, G. M., \& Zimbardo, P. G. (2012). Transformational teaching: Theoretical underpinnings, basic principles, and core methods. Educational psychology review, 24(4), 569-608.

Svinivki, M., \& McKeachie, W. J. (2011). McKeachie's teaching tips: Strategies, research, and theory for college and university teachers (Thirteenth ed.). Wadsworth: Belmont, CA.

Sweller, J. (1999). Instructional design in technical areas. Camberwell. Australia: ACER Press.

Tapscott, D. (1998). Growing up digital. The rise of the ne generation. McGraw-Hill, New York.

Wang, M. T., \& Degol, J. (2014). Staying engaged: Knowledge and research needs in student engagement. Child Development Perspectives, 8(3), 137-143. 
INTERNATIONAL JOURNAL OF ACADEMIC RESEARCH IN PROGRESSIVE EDUCATION AND

DEVELOPMENT

Vol. 9, No. 4, 2020, E-ISSN: 2226-6348 @ 2020 HRMARS

Wang, M. T., Eccles, J. S. (2012). Adolescent behavioral, emotional, and cognitive engagement trajectories in school and their differential relations to educational success. Journal of Research on Adolescence, 22(1), 31-39.

Wetzel, C. D., Radtke, P. H., \& Stern, H. W. (1994). Instructional effectiveness of video media. Lawrence Erlbaum Associates, Inc.

Zhen, Z. (2016). The use of multimedia in English teaching. US-China Foreign Language, 14(3), 182-189. 